\title{
Environmental Education for Early Childhood through Planting Activities in Khansa Kindergarten (TK Khansa) Medan
} \author{
Wini Dirgahayu ${ }^{3}$ \\ ${ }^{1)}$ Faculty of Forestry, Universitas Sumatera Utar, Medan, North Sumatra, Indonesia \\ ${ }^{2}$ Student of Faculty of Forestry, Universitas Sumatera Utara \\ ${ }^{3}$ Student of Universitas Panca Budi, Medan
}

Rahmawaty $^{1 *}$, Ma'rifatin Zahrah', Ridahati Rambey ${ }^{1}$, Ruth ME Marpaung',

\begin{abstract}
The school garden can be used for planting various types of plants. So that the use of land is more optimal, then one of the efforts that can be done is to invite students to plant various types of plants, such as vegetables, ornamental plants and fruits as well as medicinal plants. These plants can be placed in the school garden, both in the front and in the back. This activity aimed to provide environmental education for early childhood through planting various types of plants and introducing various types of plants in early childhood and to increase the type of vegetation/plants in the front and back yards of TK Khansa to make it look greener and more beautiful. There were some steps of activities, namely: preparation of planting media, planting, and harvesting of fast-growing type of vegetables. Based on the results of the activities, that the children were very enthusiastic and very happy through planting various types of plants in their school grounds. In addition, with this activity, the situation and the conditions in the Khansa Kindergarten School environment becomes more beautiful with the planting of various plants in the front and back yards of the school and become comfortable with the presence of various types of flowers and other plants.
\end{abstract}

Keywords: Childhood, Environmental education, Garden, Plants

Abstrak. Lahan pekarangan sekolah dapat dimanfaatkan untuk penanaman berbagai
jenis tumbuhan. Agar pemanfaatan lahan lebih optimal, maka salah satu upaya yang
dapat dilakukan adalah mengajak anak didik untuk menanam berbagai jenis
tanaman, seperti: sayur-sayuran, tanaman hias dan buah-buahan serta tanaman
obat-obatan. Tanaman tersebut dapat diletakkan di pekarangan sekolah, baikdi

*Corresponding author at: Jl. Tri Dharma Ujung No.1 Medan 20155 North Sumatra Telp./fax. +62-61-820-1920

E-mail address: rahmawaty@usu.ac.id

Copyright ( 2018 Published by Talenta Publisher, ISSN: 2621-4830

Journal Homepage: https://talenta.usu.ac.id/jst 
bagian depan maupun di bagian belakang. Kegiatan ini bertujuan untuk memberikan pendidikan lingkungan pada anak usia dini melalui penanaman berbagai jenis tumbuh-tumbuhan dan memperkenalkan berbagai jenis tumbuhan pada anak usia dini dan menambah jenis vegetasi/tumbuhan di halaman depan dan belakang TK Khansa agar terlihat lebih hijau dan indah.Tahapan kegiatannya dimulai dari penyiapan media tanam, penanaman, dan pemanenan jenis sayuran yang cepat panen. Berdasarkan hasil kegiatan yang dilakukan, terlihat bahwa anak-anak sangat antusias dan sangat senang melakukan penanaman berbagai jenis tumbuhan di lahan pekarangan sekolah mereka. Selain itu, dengan adanya kegiatan ini, maka keadaan lingkungan sekolah TK Khansa menjadi lebih indah dan asri dengan ditanamnya berbagai macam tumbuhan di halaman depan dan belakang sekolah.Kondisi TK Khansa menjadi nyaman dengan kehadiran berbagai jenis bunga dan tanaman lainnya.

Kata Kunci: Anak usia dini, Pendidikan lingkungan, Pekarangan, Tanaman

Received 20 January 2020 | Revised 15 March 2020 | Accepted 25 March 2020

\section{Introduction}

Education is learning process that can improve human behavior, attitudes and intellectual. Education needs to be developed including the development of environmental values in early childhood. Early childhood is a golden age (the golden age) that has the potential to train and develop various multi-intelligence potentials of children [1][2]. It is a crucial age in shaping the character and personality of children [3][4], the age when children experience rapid growth and development [5] and the most important and basic early period in the entire range of growth and development of human life [2]. This period is marked by various important periods which are fundamental in the life of the next child until the final period of its development.

The environment around children is one source of learning that can be optimized for the achievement of quality educational processes and outcomes for young children [6]. Real environmental conditions will also attract the spontaneous attention of children so that children have an understanding and wealth of knowledge that comes from their own environment.

Students at the Khansa Kindergarten have not been introduced and have not been taught directly outside the classroom about various types of plants, such as: vegetables, fruits, ornamental plants and medicinal plants. Likewise, with how to plant crops, such as: seed preparation, planting media, care and harvesting. Khansa Kindergarten school yard which is very possible to do the planting of various types of plants.. At present, there are 
only about $20 \%$ of vegetation in Khansa Kindergarten. In the front yard of the Khansa kindergarten there is Polyalthia longifolia (Figure 1) and in the backyard, there is a Syzygium aqueum tree. There is still a lot of room in the front and back yards that can still be planted with various types of plants. therefore, community service activities at this school need to be carried out.

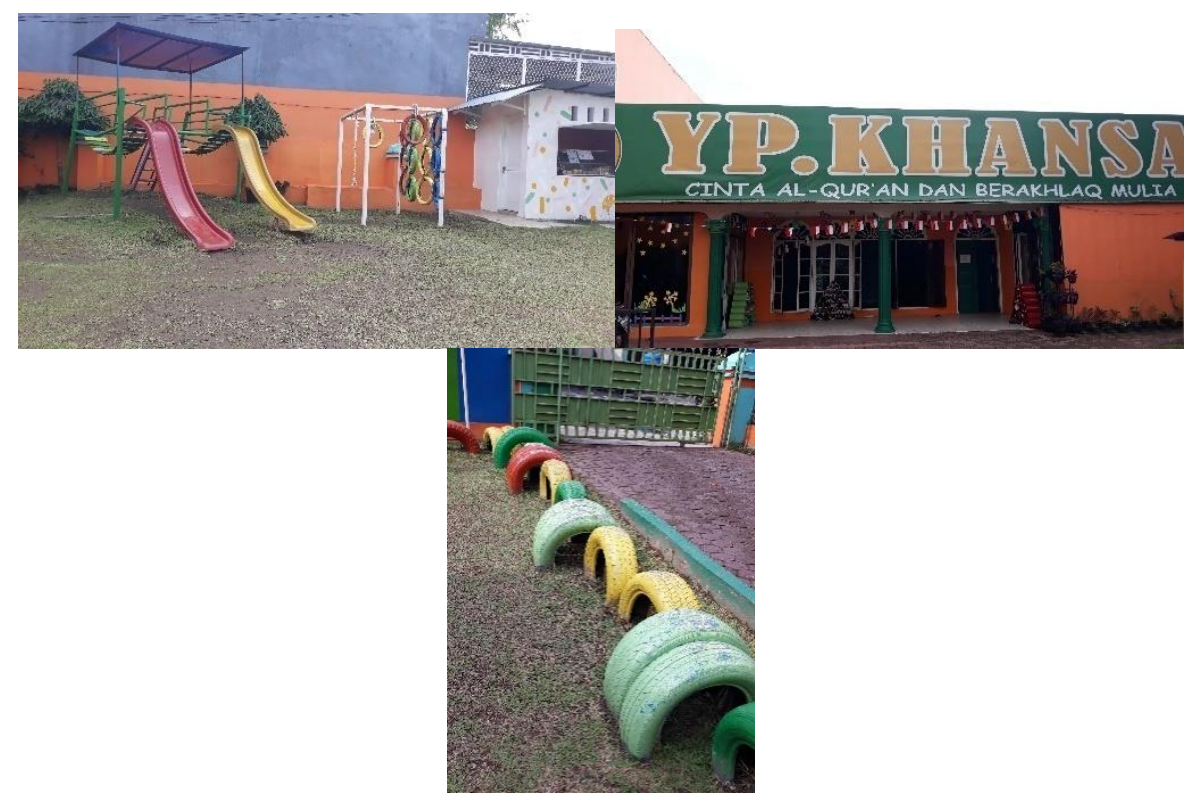

Figure 1. The situation of Khansa Kindergarten before community service activities

The current condition of the Khansa Kindergarten School has not maximized the use of the school yard to be planted with various types of plants. In addition, students at the Khansa Kindergarten have not been introduced to environmental education. One way to teach children to love plants is to practice planting various types of plants. Therefore, Khansa Kindergarten students need to be introduced and given direct education about how to get to know the environment. This community service activity aimed to provide environmental education for early childhood through planting various types of plants and introducing various types of plants in early childhood and to increase the type of vegetation/plants in the front and back yards of Khansa Kindergarten to make it look greener and more beautiful.

\section{Methods}

\subsection{Time and location}

This activity was carried out from May to August 2019 at Khansa Kindergarten, Medan City (Figure 2). It is located on Jalan Setia Budi Tanjung Sari, Medan Selayang District, Medan City. 


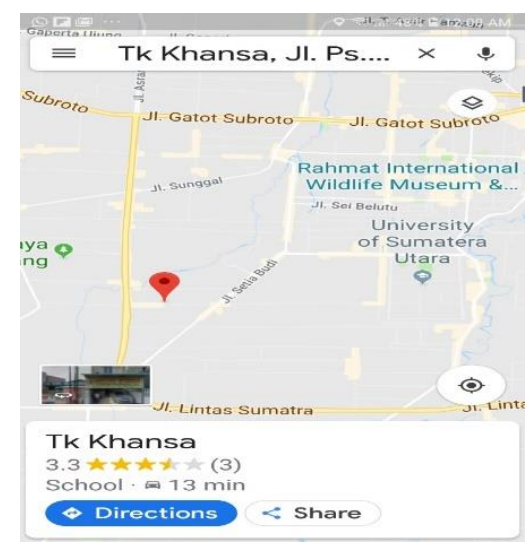

Figure 2. Map location and Khansa Kindergarten

\subsection{Methods}

This activity consists of several steps, namely: preparation of activities, implementation of activities in the field, processing data and presenting the results of activities. In the preparation step, the activities carried out are preparing all the necessary equipment, such as: gloves, polybags / pots, planting media, tools for planting, and seeds to be planted. To plant plants in polybags / pots, planting media must be prepared first. This growing media is one of the factors in plant growth and influences the yield of its production as well. The function of the planting medium itself is to support the plant, as a place where the roots of the plant develop and grow, and provide nutrients for plants. Planting plants in polybags / pots, need a good planting medium as a substitute for soil. A good growing media in crop cultivation, which has the appropriate physical, biological and chemical properties so that plants can flourish and develop quickly. Steps taken to prepare planting media for crop cultivation in polybags, are: prepare loose and fertile soil, then sift until it becomes fine grains. For land that is taken, try to dry it to make it easier to mix and evenly distributed; prepare compost, then sift it into fine granules; prepare husk charcoal for the mixture; mix fine soil, fine compost, and husk charcoal until evenly mixed with a ratio of 2: 1: 1. Next is to prepare a poly bag/pot, then enter the planting media that has been mixed earlier.

After the planting media has been prepared, the next step is to prepare the seedlings of plants that you want to plant into polybags/pots to be planted on the planting media. For seeds try to choose one that has good quality so the results will be good too. At the implementation step in the field, what is done is planting the seeds, caring and harvesting. Plant the seeds into a prepared polybag/pot, make a hole in the middle of the polybag/pot about $5 \mathrm{~cm}$ deep, then plant the seeds. Next, cover the edges of the seedlings until the seeds are fully embedded. The last step to do is care for plants. One treatment that must be done is to clean the weeds that grow around the plant. In addition, the removal of pests is also 
important so that plants grow more fertile. Plants are regularly watered for nutritional needs. For vegetables, after a few months can be harvested. Harvest vegetable shrubs that are picked by the leaves can be picked at the age of 35-40 days. Harvesting can be done at intervals of 3-4 days. For Amaranthus spinosus. and Ipomoea aquatica, directly by uprooting the plant and its roots.At the step of data processing and presentation of the results of activities. All data obtained in the form of measurement results are recorded and documentation in the form of photos and videos. Then the results obtained are presented in the form of activity reports and videos uploaded on YouTube with the link: https://www.youtube.com/watch?v=5eo_818JH38.

The method used in introducing plant species to Khansa Kindergarten students is by dividing students into five groups and planting each type of plant. The composition of the planting media used was top soil, rice husk and compost [7][8][9][10]. Plants that are planted, such as fruits, vegetables, flowers, and medicinal plants (Figure 3). The types of fruit planted are avocado (Persea americana), jambu air (Syzygium aqueum), mango (Mangifera indica), jambu bol (Syzygium malaccense), and kasturi oranges (Citrofortunella microcarpa). Types of vegetables planted are Amaranthus spinosus, Ipomoea aquatica,Brassica chinensis, Allium cepa. Types of vegetables planted are the types of vegetables commonly consumed by children and have high nutritional value.

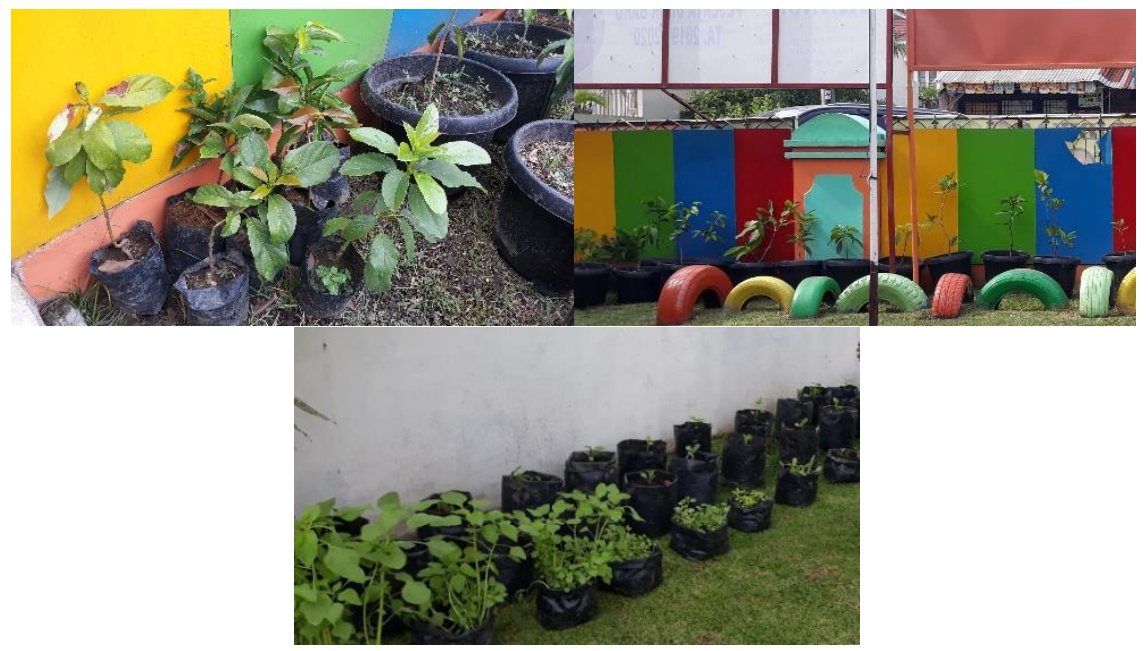

Figure 3. Plants that are planted in Khansa Kindergarten

Vegetable identification method used is by dividing small groups accompanied by a team of devotees and teachers ranging from how to fill polybags with topsoil and compost mixed media to how to plant. After finishing planting polybags containing vegetables placed in a safe place and watered every day. Ginger and galangal are types of plants that can be planted in polybags so that they can be planted in the school environment. With the introduction of medicinal plants, kindergarten students 
understand the types of medicinal plants. Galangal is a traditional medicine for cold and cough. Ginger is a food ingredient as well as beneficial for medicine to warm the body. Type recognition method to kindergartners who done is by the practice of directly growing ginger and galangal.

The types of flowers planted are potted ornamental plants such as Hedyotis corymbosa, Asparagus densiflorus, various types of tamarind flowers, Lilium spp., aloe vera, Adiantum capillus, and others. The method of introducing the types of flowers is carried out by dividing students into small groups accompanied by a team of devotees and teachers. Pots and polybags that have been planted fruit/vegetables/flowers/medicinal plants were placed in the school yard and watered every day. The evaluation method used for community service activities was a direct visit to the location conducted by the monitoring and evaluation team of the Universitas Sumatra Utara. Direct assessment is carried out by the team.

\section{Results and Discussions}

Environmental education activities in Khansa Kindergarten can be seen in Figure 4 and Figure 5. Students were very happy and eagerly to get involved in planting activity. By learning benefits of each plants, children understand the benefit of the planting activity and humans'role in protecting the environment. This method was done to make students aware of their duties and responsibilities, namely protecting nature and the environment, installing to students that every living thing including plants has a function for the environment. This method can also teach kindergartners to love nature with simple things.
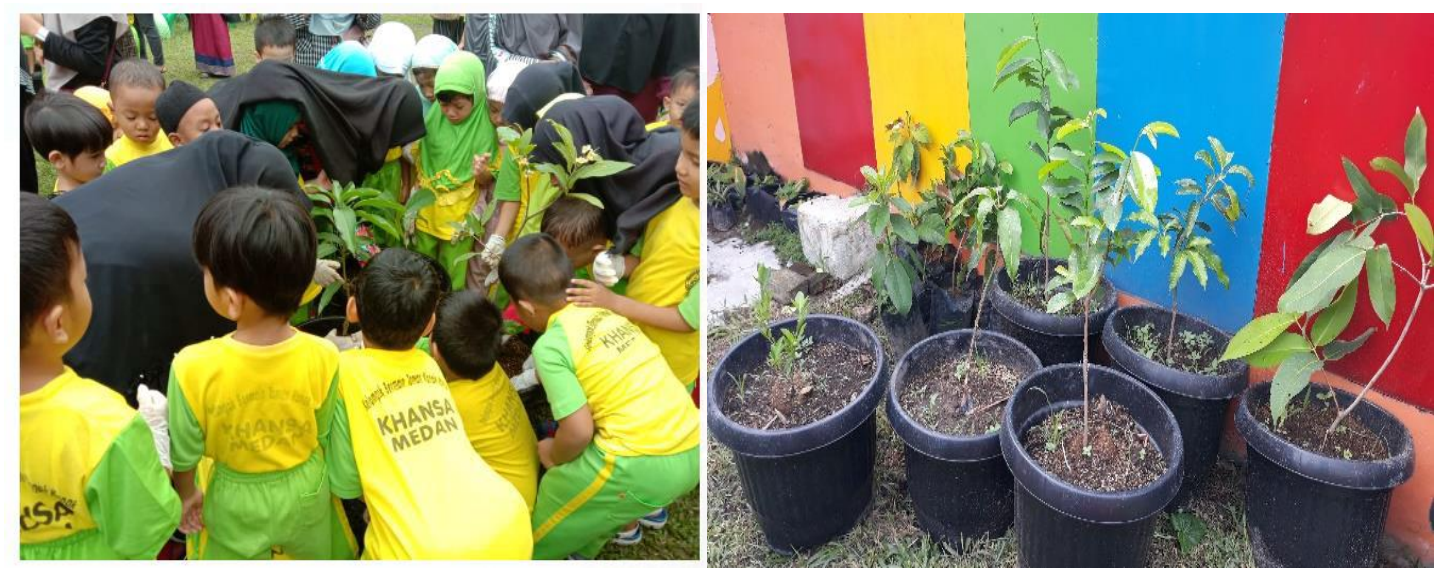

Figure 4. Planting fruits by children of Khansa Kindergarten 


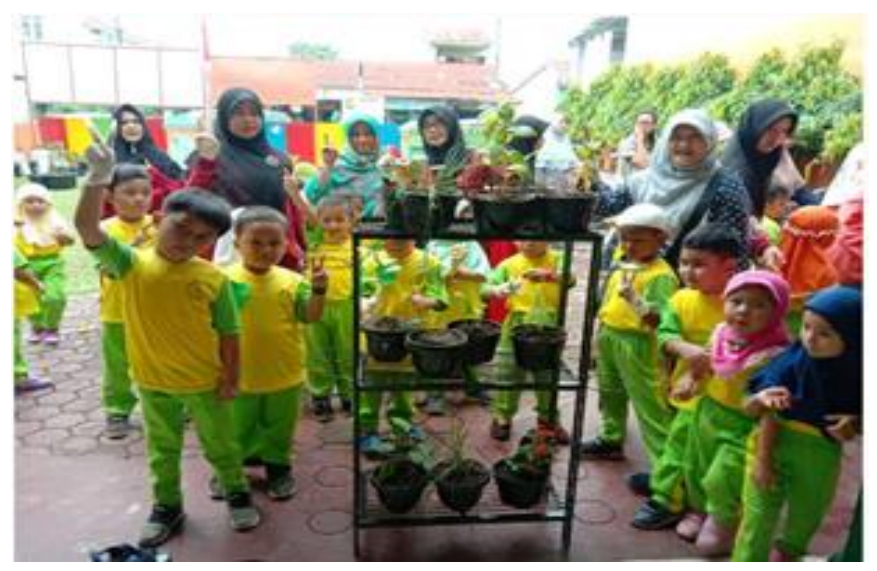

Figure 5. The reaction of Khansa Kindergarten children after planting

In addition, children were also taught to manage waste by making potted plants from used bottles. They also harvest the vegetables and cook them at school and learn to like vegetables [11][12][13][14].

The response of teachers, principals and chairpersons of the Khansa Kindergarten Foundation was very positive towards the community service program. The school was very enthusiastic to cooperate in environmental education for students in their schools. This can be seen from the attitude of the teachers who pro-actively assist students when planting activities take place. The same response was shown by students on the day of planting. Students are very excited to get the first chance to grow fruit and vegetable crops. Before planting, the program implementers first introduce all types of plants to be planted to both teachers and students.

The results of vegetable growing activities in Khansa Kindergartencan be seen in Figure 6. Figure 6 shows that at the age of 3 days planted spinach has reached a height of $1.5 \mathrm{~cm}$. after the age of 1 week increased by $5 \mathrm{~cm}$ to $6.5 \mathrm{~cm}$. Khansa Kindergarten children were very happy to observe the growth of their plants, since the process of the plants began to grow to form leaves. By observing the plants growth on daily base, the students started love their environment.

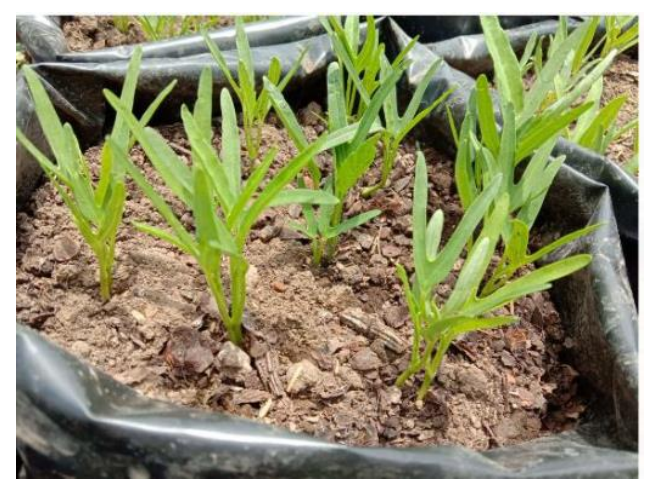

Figure 6. Spinach (Amaranthus spinosus) age 1 week with $6.5 \mathrm{~cm}$ height 
The results of flower planting activities at Khansa Kindergarten, can be seen in Figure 7 and Figure 8.
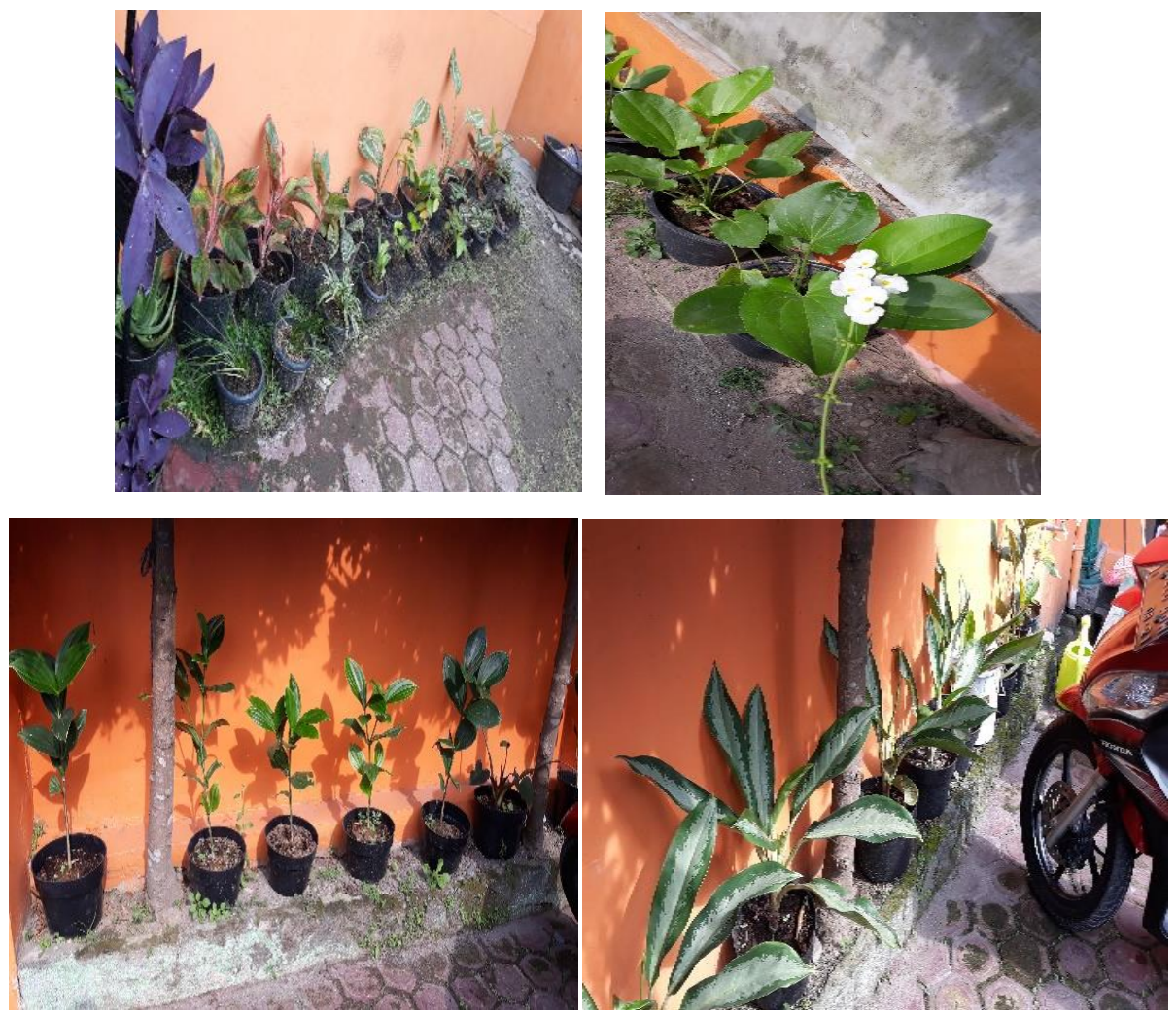

Figure 7. The flowers planted by KhansaKindergarten children

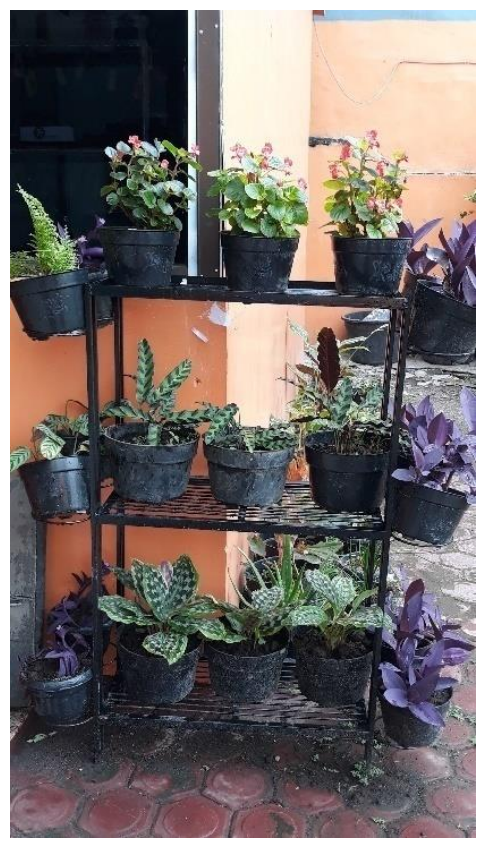

Figure 8. Arrangement of flowers produced by Khansa Kindergarten children 
Based on Figure 7 and Figure 8, it can be seen that after this activity, the conditions of their school become comfortable with the presence of various types of flowers and other plants. Beautiful school conditions can make students feel at home to be in school. With this activity, the Khansa kindergartner began to be equipped with simple environmental education. Thus, it is in accordance with the notion of environmental education [15][16], which is an educational program to foster children or students to have understanding, awareness, attitudes, and behavior that is rational and responsible for the mutual influence between living things and the environment live in various aspects of human life.

Khansa kindergarten has a yard/garden which is quite extensive, but ecologically it has not been utilized to its full potential. As mentioned earlier, that in Khansa Kindergarten there are only about $20 \%$ of vegetation. As There is a grassy green open space in the front yard and backyard of the school building. Along the edge of the front yard, Glodokan Tiang (Polyalthia longifolia) trees were planted, while in the backyard, they are planted with poorly maintained jambu air trees. Ecologically, the Polyalthia longifolia is a green evergreen plant all year round so it is suitable for reducing air pollution. In general school conditions, no other types of plants have been planted so they appear less beautiful. There is still room in the yard/yard that can still be used for planting other types of plants.

Successful implementation of the environmental education program at Khansa Kindergarten is said to be achieved when there has been a change in the behavior of students in acting to love their environment, in this case concern for the surrounding plants. Based on the results of visits and evaluations by the monitoring and evaluation team (Figure 9), that this dedication activity is very useful and provides environmental education.

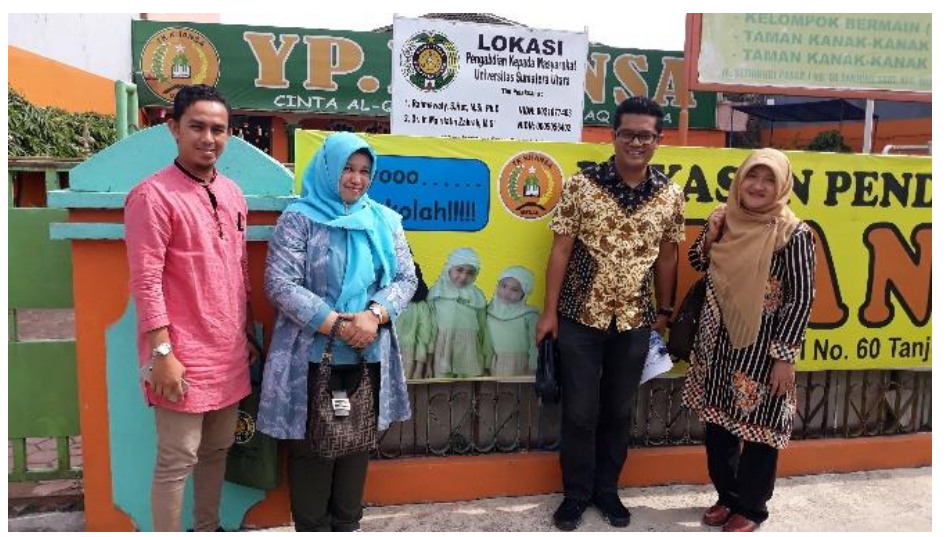

Figure 9. The community service team with monitoring and evaluation team in front of Khansa Kindergarten 
Students who are initially unfamiliar with plants of fruits, vegetables, ornamental plants and medicinal plants are expected to start recognizing these plants. In addition to knowing the type, students are expected to simply already know how to plant and water the plants. If this behavior is repeated continuously from both the teacher and parents in their respective homes, the care and love of students towards fellow creatures of God in the form of plants in particular and the environment in general will be realized as expected. Children's concern for the environment needs to be raised gradually and continuously so that later true awareness in life will be realized to always care for the environment. Furthermore it is said that the cultivation of love and care for the environment must start early, especially starting from the family, despite the fact that not many families do so. For this reason, the role of schools is important in shaping this character [17].

The children must begin to be implanted that humans are part of nature and must apply both to nature (ecosentrism ethics), not vice versa, that nature is an object, tool and means for meeting human needs (anthropocentrism ethics) [12]. To raise students' awareness of the surrounding environment, it must be done by touching the heart. If the awareness process has occurred, then there will be a change in attitude and mindset towards the environment. The process of awareness is a core process, which must continue to be developed step by step [18][19][20]. Activities of introducing species and planting plants to young children in Khansa Kindergarten that have been carried out, can foster a sense of care for the environment and increase children's insights about the types of plants and how to plant these plants. The children were very happy when planting and watering the plants that were planted together.

\section{Conclusions}

The existence of community service activities, make the kindergarten children know about the types of plants such as fruits, vegetables, flowers, and medicinal plants, as well as how to plant these plants. The conditions of Khansa Kindergarten now, look greener and more beautiful by planting various types of plants. Vegetation covers in Khansa Kindergarten increased with the existence of community service activities.

\section{Acknowledgments}

Thank you to the Universitas Sumatera Utara (USU) Community Service Institution (Lembaga Pengabdian pada Masyarakat, USU) for the funding through NON PNBP of the USU with the Contract Number: 331/UN5.2.3.2.1/PPM/2019, May 20, 2019. Thank you to USU's forestry students who have helped with this activity. 


\section{References}

[1] Word Health Organitation. Fact Sheet Diabetes. Dari http://www.who.int/mediacentre. 2015.

[2] M. Winnie, Edward, Edodge, C. M. Auxilia, and M. George, "Nonadherence to treatment among diabetic patients attending outpatients clinic at Mutare provincial hospital". Manicaland province, Zimbabwe, vol. 3, pp. 66-86, 2014.

[3] R. Wilson, Nature and Young Children: Encouraging Creative Play and Learning in Natural Environments. London. Routledge. 2012.

[4] M. Hedefalk, J. Almqvist, and L. Östman, "Education for sustainable development in early childhood education: a review of the research literature". Environmental Education Research, vol. 21, pp. 975-990, 2015.

[5] Isjoni. Model Pembelajaran Anak Usia Dini (Early Childhood Learning Model). Alfabeta, Bandung. 2010.

[6] E. Pearson and S. Degotardi, "Education for sustainable development in early childhood education: a global solution to local concerns". International Journal of Early Childhood, vol. 41, pp. 97-111, 2009.

[7] Halida, "Pembelajaran terpadu pada anak usia dini (Integrated learning in early childhood)". Jurnal Pembelajaran Perspektif. Program Studi Pendidikan Guru PAUD FKIP Universitas Tanjungpura, pp. 1-8, 2016.

[8] D. R. Sawitri, "Early childhood environmental education in tropical and coastal areas: a meta-analysis". IOP Conference Series: Earth and Environmental Science, vol. 55 , no. $1,2017$.

https://iopscience.iop.org/article/10.1088/1755-1315/55/1/012050.

[9] A. Rauf, D. Rahmawaty, Budiati, and T. J. Said, "Sistem pertanian terpadu di lahan pekarangan mendukung ketahanan pangan berkelanjutan dan berwawasan lingkungan (Integrated farming systems in the backyard support sustainable food security and environmentally sound)". Jurnal Pertanian Tropik, vol. 1, no. 1, pp. 1-8, 2013. https://doi.org/10.32734/jpt.v1i1.2864.

[10] B. Sanusi, Sukses bertanam sayuran dilahan sempit (Successfully growing vegetables in a small area). Agromedia Pustaka: Jakarta. 2010.

[11] S. Soeleman and D. Rahayu, Halaman Organik (Organic Yard). Agromedia Pustaka: Jakarta. 2013.

[12] Y. Supriati and E. Herliana, Sayuran organik dalam pot (Organic vegetables in pots). Penebar Swadaya: Jakarta. 2015.

[13] R. D. Lisminingsih, "Pembelajaran pendidikan lingkungan hidup berorientasi kecakapan hidup di sekolah dasar dan Madrasah Intidaiyah Kota Batu (learning of environmental education oriented life skills in elementary schools and Intidaiyah Madrasah in Batu City)". Prosiding Seminar Nasional Biologi, Program Studi Pendidikan Biologi FKIP Universitas Sebelas Maret, Solo, no. 257, 2010.

[14] S. Keraf, Etika Lingkungan Hidup (Environmental Ethics). PT Kompas Media Nusantara: Jakarta. 2010.

[15] A. C. Mackenzie and S. Edwards, "Toward a model for early childhood environmental education: foregrounding, developing, and connecting knowledge through play-based learning". The Journal of Environmental Education, vol. 44, pp. 195-213, 2013. 
[16] S. Hamzah, Pendidikan Lingkungan (Environmental Education). PT Refika Aditama: Bandung. 2013.

[17] Pamuti., P. Bobby, and A. Djarkasi, Kajian perencanaan pengajaran mata pelajaran pendidikan lingkungan hidup (PLH) pada tingkat sekolah dasar di Kota Manado: Jurnal Sabua.http://ejournal.unstrat.ac.id. (Accessed on 13 april 2020).

[18] R. Afandi, "Integrasi pendidikan lingkungan hidup melalui pembelajaran IPS di sekolah dasar sebagai alternatif menciptakan sekolah hijau”. Jurnal Pedagogia, vol. 2, no. 1, pp. 98-108, 2013.

[19] M.. Zahrah and C. M. Hanum,. "Pembinaan Sekolah Dasar di wilayah pesisir menuju sekolah berwawasan lingkungan (Kecamatan Mesjid Raya Kabupaten Aceh Besar, Propinsi Aceh)". Jurnal Lingkungan Tropis, vol. 7, no. 2, pp. 103-112, 2013.

[20] N. Carmi, S. Arnon, and N. Orion, "Transforming environmental knowledge into behavior: the mediating role of environmental emotions". The Journal of Environmental Education, vol. 46, pp. 183-201, 2015.

[21] J. Ernst, "Early childhood educators' use of natural outdoor settings as learning environments: an exploratory study of beliefs, practices, and barriers". Environmental Education Research, vol. 20, pp. 735-752, 2014.

[22] I. E. Palmberg and J. Kuru, "Outdoor activities as a basis for environmental responsibility". The Journal of Environmental Education, vol. 31, no. 4, pp. 32-36, 2000. 